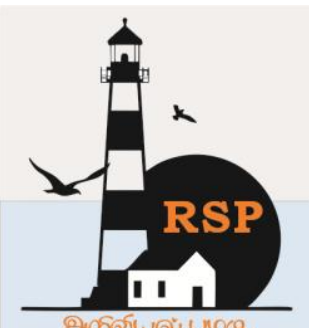

INTERNATIONAL RESEARCH JOURNAL ON ADVANCED SCIENCE HUB

RSP SCIENCE HUB

(The Hub of Research Ideas)

Available online at www.rspsciencehub.com

\title{
Building Critical Thinking in Covid-19 Pandemic Era: Impossible or I am Possible?
}

Sandy Ariawan

STIPAK Malang

Lecturer, Dept. of Christian Education, STIPAK Malang, East Java, Indonesia

ariawan.sandy@yahoo.com

\begin{abstract}
This study aimed to examine the influence of blended learning on critical thinking of Indonesian Christian students during the covid-19 pandemic era. Blended learning was a mixture of traditional learning and online learning. It was a method that students were freely to study the subject matter independently by utilizing the materials available online or conducting discussions with teachers or other students outside the hours of face-to-face, and teachers could add enrichment materials through internet facilities, might have students read the material or did the tests performed before the study. This method produced a critical thinking, which was a consideration of viewpoint, interpretation and withdrawal of conclusions, assumptions, implications, and consequences, open minds, collecting, assessing and translating relevant information. This study was a quantitative research, using simple linier regression. A hundred and twenty students were randomly selected from schools in Malang East Java Indonesia. The result reveals that blended learning influenced $81.6 \%$ adjustment of critical thinking of students. In this regard, Ministry of Education and Culture of Indonesia should on regular bases organize workshops on blended learning for teachers.
\end{abstract}

\section{Keywords: blended learning, critical thinking, Christian education}

\section{Introduction}

It was impossible to get proper education process in pandemic era. Even a year before pandemic, a research proved that teachers needed an extra hard effort to design the learning process so that students are interested in participating in teaching and learning activities [1]. It was found that role playing method influenced $34,8 \%$ on the result. It is exciting to be examined because traditional method (face to face) was prohibited during the covid-19 pandemic. So, will it be impossible to increase critical thinking, or be there a chance to gain it?

Blended learning is a mixture of traditional learning or face-to-face and online learning that uses technology [2]. In line with Usman's opinion, Widiara also said that the Blended Learning method is a mixed learning that uses face-to-face learning or direct learning with online learning so that students are more interested in learning the material [3]. Based on the above exposure, it can be concluded that Blended learning is a combination of traditional learning or commonly called face to face and online learning using technology. According to Kusairi in Hima [4], some of the impacts of Blended Learning: (a) Students are freely to study the subject matter independently by utilizing the materials available online; (b) Students may conduct discussions with teachers or other students outside the hours of face-to-face. (c) Learning activities undertaken by students in face-to-face hours can be managed and well controlled by the teacher. (d) Teachers can add enrichment materials through 
internet facilities; (e) The teacher may have students read the material or do the tests performed before the study.

From the above exposure, it can be concluded that Blended learning has some advantages that can help teachers to make it easier to convey the lesson material. In addition, Blended Learning can also facilitate students in self-learning and can easily communicate with students through technology media. So the learning process can take place well and can achieve the learning objectives.

There were steps to implement blended learning, according to Gagne, Wager, Golas, \& Keller in Sihabudin [5] as follows: a. Get students' attention (gaining attention), which means attracting students' attention with new things; $b$. Tell students about the informing learner of lesson objective, which means the teacher tells students what to accomplish; c. To view previous learning (stimulating recall of prior learning), that means the teacher is reminding back about the previous lesson; d. Presenting stimuli with different/distinctive features, means use method to present and cue the lesson content to provide more effective and efficient instructions; e. Provide learning guidance (guiding learning), which means teachers help students to learn the material that the teacher presents; f. Generate performance (eliciting performance), which means teachers help students to embed new skills and knowledge to confirm the correct understanding of the material the teacher teaches; g. Give feedback (providing informative feedback), which means giving direct feedback on students' performance to assess and facilitate learning; h. Assessing performance, means that teachers evaluate the learning process and see if the learning outcomes are in accordance with the learning objectives; i. Improve the retention and transfer of learning.

The UFMCS Handbook presented some expert opinions on critical thinking. Critical thinking was a consideration of viewpoint, interpretation and withdrawal of conclusions, assumptions, implications, consequences, open- minds, collecting, assessing and translating relevant information [6]. This group of activities encourages one to sharpen the analytical and presentation skills of an alternative solution in a problem. The expertise of critical thinking skills allowed one to finish the job effectively with efficient fan. In addition to solutions, critical thinking activities also gave a person a readiness in accepting the consequences on the decisions that have been made.

According to Brookfield in UFMCS Handbook, the critical thinking was how one responds to the assumption and investigated another alternative to the assumption. It was briefly explained that the process of thinking in critical thinking consisted of two activities: responding to assumptions and investigating alternatives. In response to a person's assumption student must have adequate and extensive knowledge about the assumption. That knowledge included the clarity of the problem of what, involving who and impacting anyone. While investigating alternatives included the worst and best possibilities that would roughly happen when using a solution.

Critical thinking is the awareness in linking questions, it is also the ability and willingness to ask and answer according to time. Looking at the first word "consciousness," the critical thinking was a process of thinking that was done consciously and intentionally. Then the awareness and openness in the thinking was directed to how one connected the questions that certainly require answers. In this case the question was the problem. The answer was the solution to the problem.

According to Jason in UFMCS Handbook, critical thinking talked about how to develop views on the world and use it by drawing conclusions based on sensible reasons regarding the questions and arguments. Still containing the same outline as the opinions of other experts, Jason explained in his opinion that critical thinking was about how to consider the views agreed on almost everyone. The consideration was then adapted to the context and needs of the moment. Every conclusion taken must be reasonable and relevant as it would be applied in everyday life involving others around.

Elder said that bad thinking is costly, whether in terms of finance or quality of life. It was explained that practicing critical thinking skills was an option. When someone wanted to practice critical skills or other high-level thinking, then the gains gained by quality of life and problem solving skills were increasing. Thus, life would be more effective and efficient, whether in finance, use of time, decision making and so forth.

The above opinion was in line with the opinion of Kallet [7] which said that the purpose of critical 
www.rspsciencehub.com

thinking was to make the work effective. By further practicing the skills of critical thinking, one would be easier to live in his life. Departing from some of the above definitions, researchers could explain that critical thinking skills were a must-have skill to improve the quality of life so that it generates effectiveness and efficiency in life.

\section{Methods}

This study was a quantitative research, using simple linier regression. A hundred and twenty Christian students were randomly selected from schools in Malang East Java Indonesia.

The instrument for measuring critical thinking was a questionnaire, consist of 27 questions. Then the instrument has been validated by the product moment pearson correlation in $95 \%$ level of confidence. The reliability score obtained by Cronbach's Alpha was 0.93, which means that each item was reliable to the implement.

\section{Results and Discussion}

The results of the descriptive analysis were described below:

Table.1. Independent and Dependent Variable

\begin{tabular}{|c|c|c|c|}
\hline $\begin{array}{c}\text { Mode } \\
1\end{array}$ & $\begin{array}{c}\text { Variables } \\
\text { Entered }\end{array}$ & $\begin{array}{c}\text { Variables } \\
\text { Removed }\end{array}$ & Method \\
\hline 1 & $\mathrm{X}^{\mathrm{b}}$ &. & Enter \\
\hline
\end{tabular}

a. Dependent Variable: Y

b. All requested variables entered.

Based on Table.1, it could be described that the variable entered was variable $X$, while the variable $\mathrm{Y}$ as the dependent variable.

Table.2. Model Summary

\begin{tabular}{|c|c|c|c|c|c|}
\hline $\begin{array}{c}\text { Mo } \\
\text { del }\end{array}$ & $\mathrm{R}$ & $\begin{array}{c}\mathrm{R} \\
\text { Squar } \\
\mathrm{e}\end{array}$ & $\begin{array}{c}\text { Adjusted } \\
\mathrm{R} \text { Square }\end{array}$ & $\begin{array}{c}\text { Std. } \\
\text { Error of } \\
\text { the } \\
\text { Estimate }\end{array}$ & $\begin{array}{c}\text { Durbin- } \\
\text { Watson }\end{array}$ \\
\hline 1 & $.904^{\mathrm{a}}$ & .816 & .815 & 5.783 & 1.633 \\
\hline
\end{tabular}

a. Predictors: (Constant), $\mathrm{X}$

b. Dependent Variable: Y
Volume 02 Issue 06 June 2020

Based on Table 2, correlation coefficient (r) obtained was 0.905 . It showed a strong correlation between implementation of blended learning and critical thinking. Coefficient determination ( $\mathrm{R}$ Square) obtained was 0.816 , meant that blended learning affected critical thinking by $81.6 \%$, while $18.4 \%$ was influenced by other factors.

The classic assumption test is a statistical requirement that must be met on a linear regression analysis. In this study the classical assumption test consisted of a test of normality and heteroskedasticity which will be discussed as below.

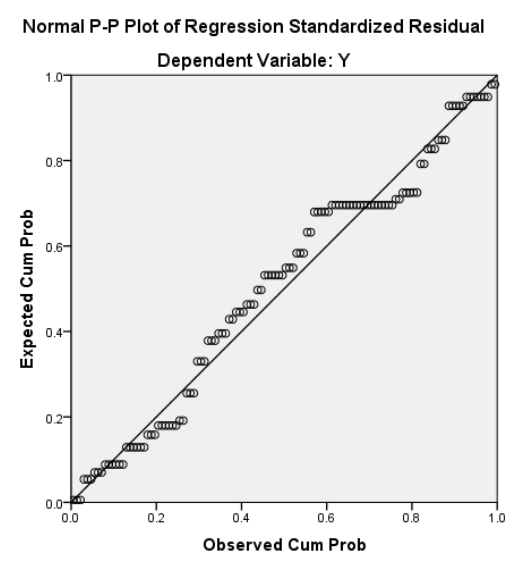

Fig.1. Normal P-P Plot

In the figure 1 of the normality of the P-P Plot above appeared that the residual was around the line, it means the data was distributed normally.

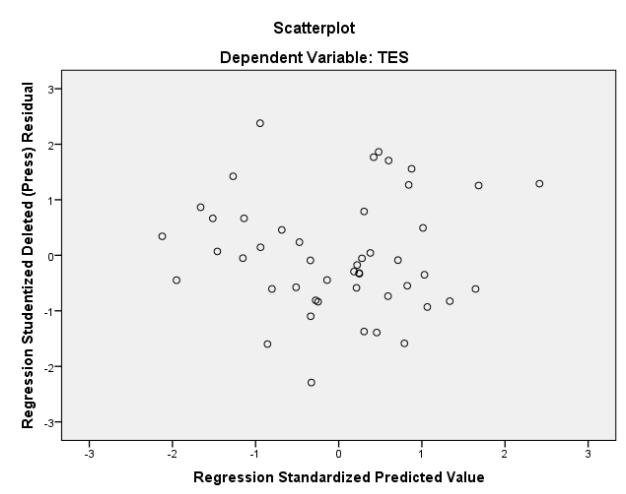

Based on figure 2 Scatterplot image above, it appeared that the dots did not form a particular pattern then this indicated that there was no problem of heteroskedasticity

On the previous research, Ariawan found that cooperative learning method was effective in 
Christian education. It showed that cooperative learning method could be used to build student's character [8]. Further from the analysis it was found that cooperative learning could be part of blended learning, which could increase critical thinking. Blended learning had some advantages that could help teachers to make it easier to convey the lesson material. Blended learning could also facilitate students in self-learning and can easily communicate with students through technology media. So the learning process can take place well and can achieve the learning objectives, which was increasing critical thinking. The process of thinking in critical thinking consisted of two activities: responding to assumptions and investigating alternatives. In response to a person's assumption student must have adequate and extensive knowledge about the assumption. That knowledge included the clarity of the problem of what, involving who and impacting anyone. While investigating alternatives included the worst and best possibilities that would roughly happen when using a solution [9] All of these was really necessary in building a good character as a base of cognitive, affective, and psychomotor aspects [10].

\section{Conclusions}

There was no doubt that blended learning could be a solution to increase critical thinking during the Covid-19 pandemic era. As current literature proved students were freely to study the subject matter independently by utilizing the materials available online, conduct discussions with teachers or other students outside the hours of face-to-face, learning activities undertaken by students in faceto-face hours could be managed and well controlled by the teacher, teachers could add enrichment materials through internet facilities, the teacher might have students read the material or do the tests performed before the study.

The result reveals that blended learning influenced $81.6 \%$ adjustment of critical thinking of students. In this regard, Ministry of Education and Culture of Indonesia should on regular bases organize workshops on blended learning for teachers.

\section{References}

[1] Ariawan, S. (2019). Countering Zeitgeist of Self-Centered through Role Playing Methods among Junior High School
Students. International Journal of Education and Curriculum Application, 2(3), 44-49. https://doi.org/10.31764/ijeca.v2i3.2143

[2] Usman (2018). Komunikasi Pendidikan Berbasis Blended Learning dalam Membentuk Kemandirian Belajar, 138.

[3] Widiara, K. (2018). Blended Learning Sebagai Alternatif Pembelajaran di Era Digital. 56.

[4] Hima, L.R. (2017). Pengaruh Pembelajaran Bauran (Blended Learning) terhadap Motivasi Siswa pada Materi Relasi dan Fungsi. Blended Learning, 41.

[5] Sihabudin (2016). Pengaruh Strategi Blended Learning terhadap Hasil Belajar Mata Kuliah Sejarah Pendidikan Islam pada Mahasiswa yang Memiliki Locus of Control Berbeda. Strategi Blended Learning, 76.

[6] Elder, P. "The Miniature Guide to Critical Thinking Concepts and Tools," London: Roman \& Littlefield, (2015).

[7] Kallet, M. "Think Smarter: Critical Thinking to Improve Problem-Solving and Decision-Making Skills," New Jersey: Wiley, (2014).

[8] Ariawan, S (2018). The Effectiveness of Cooperative Learning Method (Student Team Achievement Divisions) in Christian Education. International Journal of Education and Curriculum Application, 1(3), 45-50. https://doi.org/10.31764/ijeca.v1i3.2128

[9] Changwong, K., Sukkamart, A., \& Sisan, B. (2018). Critical Thinking Skill Development: Analysis of a New Learning Management Model for Thai High School. Journal of International Studies, 11(2), 3748.

doi.org/10.14254/2071-8330.2018/11-2/3

[10] Ariawan, S. "Kreativitas Mengajar dan Implementasi Konsep Pastor-Teacher," SulSel: CV. Mitra Ilmu, (2020). http://doi.org/10.31237/osf.io/xe95j 